Historic, Archive Document

Do not assume content reflects current scientific knowledge, policies, or practices. 



\section{SEE BACK OUTSIDE COVER}

\section{H U N T I N G T O N'S}

SEEDS of PERENNIAL

\section{छ BIENNIAL PLANTS}

As varieties and prices of these items seldom change we will not send this to you each season. Subject to crop failure we will be able to fill any item offered as long as we are in business.

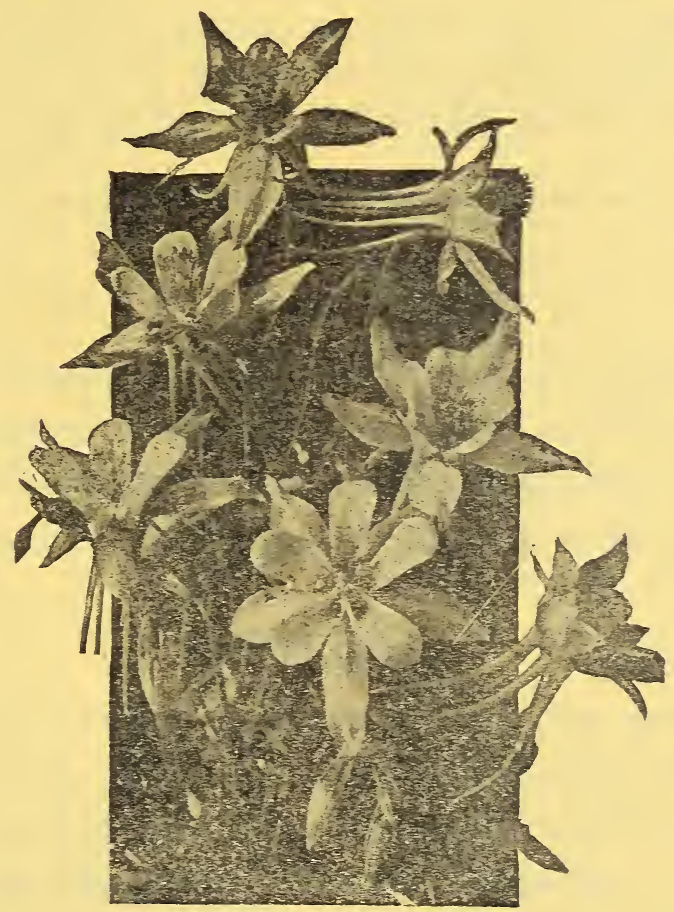

AQUILEGIA, Long Spurred-Mrs. Scott Elliott

\section{RALPH E. HUNTINGTON PAINESVILLE, OHIO, U. S. A.}




\section{To the Buyer}

In presenting this list of seeds, my whole effort has been to place before you the best and widest possible list of really good, fresh, and true seeds. By offering them in this manner, I am able to price them as low as seeds of like quality can be handled.

\section{ORDERING-IMPORTANT}

The highest grade annual seeds offered by the best houses, come from very much the same sources, wherever you buy them, and comparatively near by, hence it is an easy matter to keep in touch with the crops and to avoid listing crop failures. On the other hand, very much so, the seeds in this list come from all over the world. It is absolutely impossible for us to learn of crop failures of many items until long after the printer has our catalogue finished. If the buyer, in placing an order, will name one or two second choice items it will be of great help to us, and will insure $100 \%$ delivery.

\section{GERMINATION}

I do not guarantee germination, either in frames or outside, but I do guarantee at least $90 \%$ in an approved test. So many causes may contribute to failure that a guarantee of germination is impossible. Condensed directions for growing are sent out with each order.

\section{QUANTITIES}

Except in new or very scarce items, each packet will contain from one to five hundred seeds, according to value per ounce. Trade packets will contain at least three times the quantities of the packets, and in most cases 1000 seeds. Many new and scarce items are bought by the thousand seeds instead of by weight. Some costing us as high as $\$ 8$ per 100 , and these are priced accordingly.

Jobbers or growers please write for ounce or pound prices on your wants. 
The seeds offered in this list, such as are not gathered on the Painesville nurieries, come from all over the world. Grop information on most of these is im. possible, hence I do not dare offer them in quantity. It often happens that we have many items in good quantity, which are only quoted in packets. Send in your planting lists for quotations.

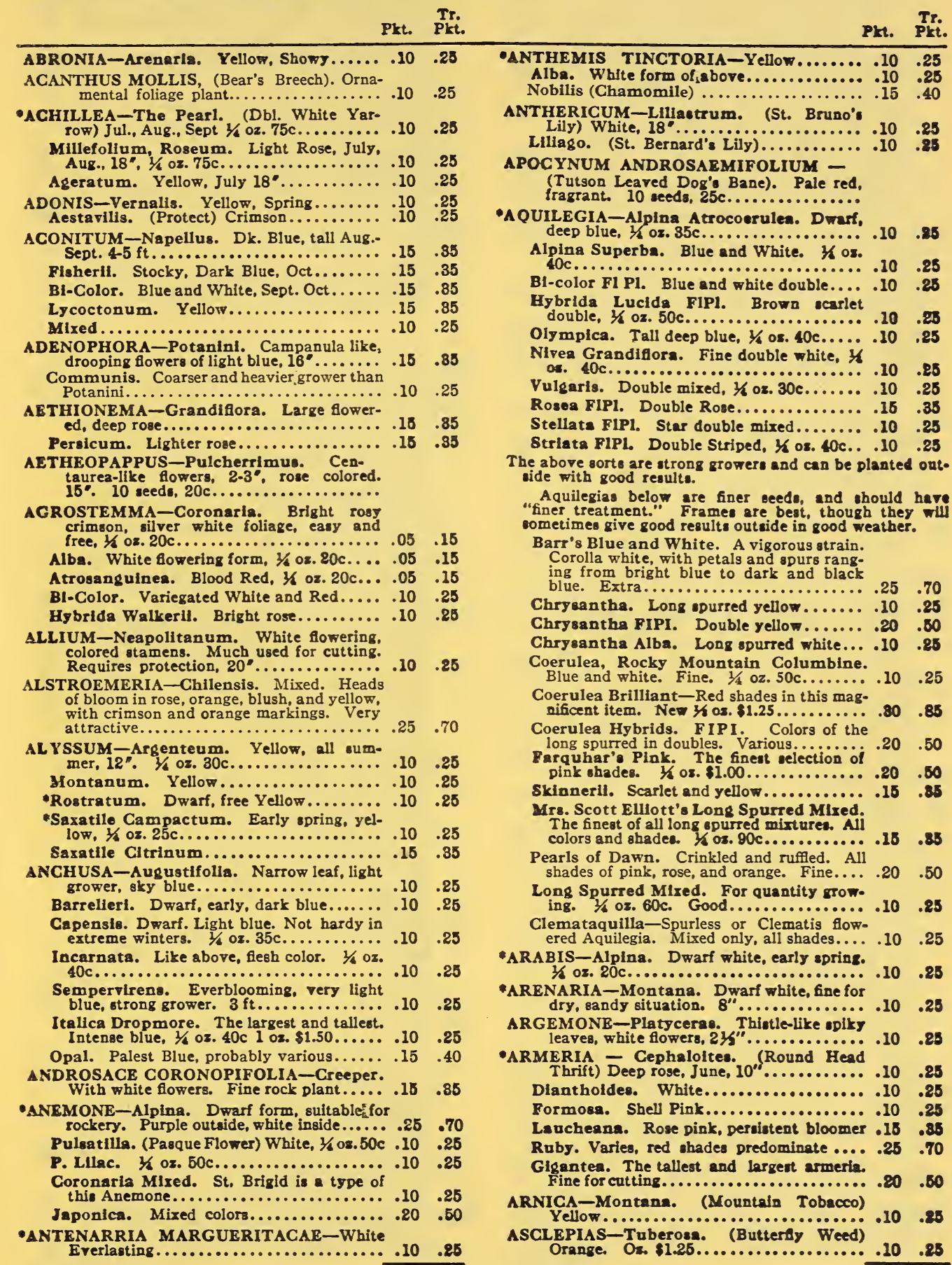

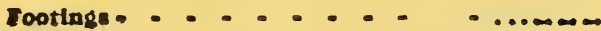

Jootluge - - - . - - - .... - -

NOTICE-Instead of writing out long lists, items may be checked and footed and the catalog returned to us. A new one will be sent with the seeds. See outside back cover. 
"ASPERULA-Odorata (Sweet Woodrufi) 1/4 oz. $10 \mathrm{c} . \ldots \ldots \ldots \ldots \ldots \ldots \ldots \ldots \ldots . .10 .28$

Hexaphylla. White, fine for cutting....... . 10 .25 ASPHODELUS-Creticus. (Asphodelene Laburnica) Straw................., 10 .25

Linurnicus. Shorter spike than the type.. . $.20 \quad .40$

Euteus. Bright yellow................10 .25

ASTER-Mired from a fine collection, $K$ KO. soc...........................10 .25

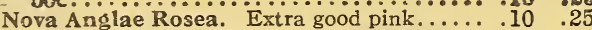

Peggy Ballard. A great favorite in England.

Rosy Mauve..............................

Acris. Well rounded little plant, 10-12" tail simply covered with medium sized flowers of blue. Good rock plant..................

Alpinus. Dwarf sorts mixed, $1 / 2$ oz. $50 \mathrm{c} . . .10$

Amellus. Taller sorts, $3 / 4$ oz. $50 \mathrm{c} . . . . . . .1 \mathbf{6}^{\circ}$

tall, easy and free. $1 / 40 z . \$ 1.00 \ldots \ldots \ldots$.

ASTRANTIA-Major. Pink .................

*AUBRITIA-Easily grown Alpine trailers. Early and free. Beautiful in the rock garden.

Gracea. Very dwarf blue. $1 / 4$ oz. $50 \mathrm{c} . . .$.

Hondersonil. Largest, reddish blue, $1 / 6 \mathrm{oz}$.

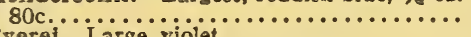

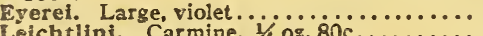
Hybrida. All colors. $3 / 4$ oz. $60 \mathrm{c} . \ldots \ldots \ldots . .$. Selected from extra dwarf, close growing varieties. Mixed colors. Very choice. $1 / 4$ oz. $\$ 2.00 \ldots \ldots \ldots \ldots \ldots \ldots \ldots \ldots \ldots \ldots \ldots \ldots . .25$

*BELLIS PERENNIS-(English Daisy)

Double white, $1 / 1 /$ oz. 50c............. $10 \quad 25$

Longfellow. Double rose, $1 / 4$ oz. 50c........ $10 \quad .25$

Mired. $1 / 4$ oz. $40 \mathrm{c} \ldots \ldots \ldots \ldots \ldots \ldots \ldots \ldots .10 .25$

Monstrosa. White, Rose, or Red, (Etna).

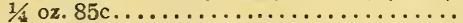

BETONICA-(Betony) Grandifora Superba. Long stems of lilac rose flowers. The best

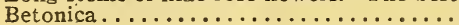

BAPTISIA-Australis. (False indigo) Dark blue,

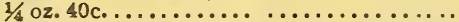

BOCCONIA-Cordata. (Plume PopDy) Tall, cream. $1 / 4$ oz. $25 \mathrm{c} . \ldots \ldots \ldots \ldots \ldots \ldots . . . . .$.

BOLTONIA-Asteroides. (False Chamomile) catisquama... Paie pink.................

BUDDLEYEA-(Butterfly Bush) Magnifica. Strong lilac. Heavy grower. Long spikes of lilac scented flowers in July-Aug. $1 / 4 \mathrm{oz} .75 \mathrm{c}$.

Farquharii. Neater, more upright growth and hardier. Flower spike more compact. Light pink. $1 / 4 \mathrm{oz} . \$ 1.50 \ldots \ldots \ldots \ldots \ldots \ldots$

BUPHTHALMUM-Cordifolium. Ox Eye

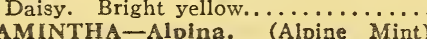

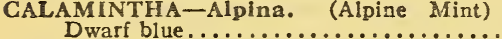
Dwarf blue....................... .20

CALLA-Mrs. Roosevelt.................10

CALLIRHOE-Involucrata. Crimson.......15

CAMPANULA-Calycanthema. (Cup and Saucer Canterbury Bells) ... B........... eparate Colors. White, Rose Blue, Striped Medium. (Single Canterbury Belis). The best grower. Separate colors, white, rose. blue, striped or mixed. $1 / 408.25 \mathrm{c}$

Medium Double. Closely built double flowers. White, Blue, Rose, Striped, or Mixed. $1 / 4 \mathrm{oz}, 25 \mathrm{c}$

Medium Dean's Hybrids. Ali colors, Double, Single, and Cup and Salicers. De. licate and deep shades. $1 / 6$ ox. $50 \mathrm{c}$..

Bononensis. Small blue flowers, very free.

* Carpatica. (Carpathian Hare Bell) Blue

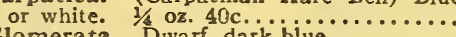

- Glomerata. Dwarf, dark blue............

Longistyla. $3 \mathrm{ft}$., bluish violet............

acrantha. Mixed blue and white, tike

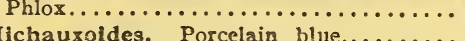

Michauxoldes. Porcelain blue,.......... light blue, extra...................

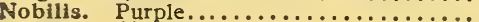
Primulaefolia. (Primula Leaved Bell Flower) Very tall. lilac.................

\section{CAMPANULA-Continued}

Persicifolla. (Peach Bells) The best perennial Campanula, white, blue or mixed. 1/8 oz. 50c. Fipi Pfitzerif. Double form of Persicifolia, blue, white or mixed ..... Rotundifolia. (Blue Bells of Scotland)....

Pyramidalis. (Chimney Bell Flower) White, blue or mired, $1 / 2$ oz. 50 c..................... yramialls Compacta. Semi-dwarf mix-

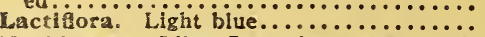

Turbinata. Like Carpatica, taller, blue,

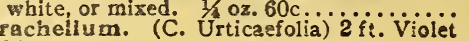

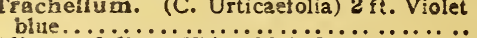
Allariaefolla. white, $18-24 \ldots \ldots \ldots \ldots . . . . .$. Latifolia. Blue, White, or mixed, $3-4 \mathrm{ft} .$. $1-2$ ft............................

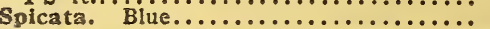
CASSIA-Marylandaica. Tall yellow, July

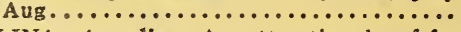

CARLINA-Acaulis. An attractive dwarf for dry, hot situations. Ornamental foliage and silvery thistle-like flower heads. Ht. 6 in. Good rock plant..................

\section{Carnation}

Nots, Carnations Vienna Market and Chabaud's are peren. nial, but give best results treated as Biennial. The Marguerites bloom in four months from seeds, and are bex treated as annuals.

GARNATION-Malmalson.

This is not scented. May be used as annual or biennial. Separate colors, White, Rose, Scarlet, Violet, Yellow.

25 seeds $15 \mathrm{c}$; 100 seeds $40 \mathrm{c}$. Mixed, plkt. $10 \mathrm{c}$ Tr. plkt. 25c. $1 / 3$ oz. $60 \mathrm{c}$.

Picotees. Fincly striped and variegated in all shades and combinations...............

Vienna Market. Scented. Fine for cutting. Sow in July, August, blooms next scason. Separate colors, red, rose, white or mixed. $1 / 4$ ox. 50c.....................................

Chabaud's French Market. Tailer than came as Vienna. Separate colors, white, red, yellow grounds, rose or mixed. $1 / 4 \mathrm{os}$.

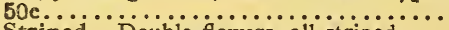

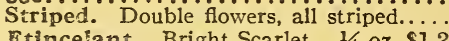
Etincelant. Bright Scarlet. $1 / 4 \mathrm{oz} . \$ 1.25$ Legiton of Honor. Salmon Shades. $1 / 4 \mathrm{oz}$.

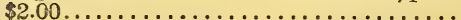

Marguerite. Smaller than Chabaud's. Blooms in August and September frora opring sown seeds. Finely scented. Good tem. Separate colors. white, rose, crimBon, yellow grounds, or mixed. $1 / 40 z .50 \mathrm{c}$.

Dianthus Alwoodii: I list this under above head for it seems to me that this is the proper place for it. Really a hardy perennial carnation, and the only one I know of. Extra... doubles.

CAMASSIA-(Wild Hyacinth) Mixed. A bulivous plant, native in the flat lands of the northern central states. Hyacinth-like flowers on spikes about $18{ }^{\prime \prime}$ tall. $1 / 6$ os.

CATANANCHE-Good everlasting for cutting. July, August, 10-12\% 1/6 oz. 40c.

CRNTAUREA-Macrocephala. Like tufts on terminal stems. Vellow, $5 \mathrm{ft}$. $1 / 4$ oz. $50 \mathrm{c}$

Montana. (Mountain Centaury) One of the most useful and handsome of perenniale
for the border. June, July, Aug. 12-18". for the border. June, July, Aug. 12-18".
Blue, white or mixed..................

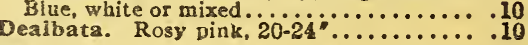

CERMALARIA-Tartarica. Fine for background of the hardy border. Large flat heads of cream yellow. $6 \mathrm{ft}$. July, Aug. .15 CERASTIUM-Tomentosum. (Snow in
Summer) White, silver leaf creeper, very

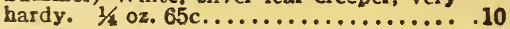

NOTICE-Instead of writing out long lists, items may be checked and footed and the catalog returned to us. A new one will be sent with the seeds. See outside back cover. 
CHAMAEPBUCB-Diacentha. (Rosette

Thistle) $1 / 3$ os. $40 \mathrm{c} \ldots \ldots \ldots \ldots \ldots \ldots \ldots \ldots .10 \quad .25$

CHIERANTHUS-Allioni. Hardy Wall Florer, yellow, free. $1 / 4$ oz. $30 \mathrm{c} \ldots \ldots \ldots \ldots \ldots$

A. Semperforens. Perpetual flowerins

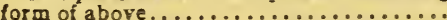

Linifolius. Alpine wallflower, Mauve...... .15

CODONOPSIS-Orata. Light blue, not reliably hardy.................... 10

COLCHICUM-Autumnale. Fall crocus... . 15 Speciosum Magnificum. The finent of the colchicums.

CONVALLARIA-Majalls, Lily of the Valley .i5

* CoRONILlA-Varia. (Crown Vetch) Pink

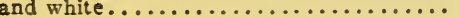

CORYDALIS-Thalictrifolia. Yellow and red.

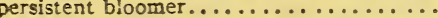

* CRUCranella - Stylosa. (Crosswort)

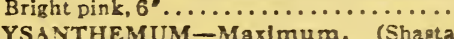

- CHR YSANTHEMUM-Maximum. (Shasta

Daisy) Alaska............ . . . . . . . . . . Mrs. J. Terstees. A fine, tall, large tower-
ing variety. Double row ot petals. $1 / 6$ os. Б0c.................................

Covent Garden Market. Hardiest, 1/6 03

Triumph. A large German variety. 1s os.

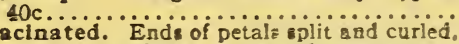
giving the flower a ragged appearance.

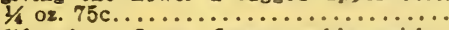

Callfornica. Large flowers, white with slight touch of yellow. $1 / 6 \mathrm{oz} .50 \mathrm{c} . . . .$.

Mrs. C. Lothlan Bell. The best example o! English selection of the light!y lacinated type. Mrs. J. Tersteeg is the best Holland selection in this line. Bo:h are good. $1 / 408$.

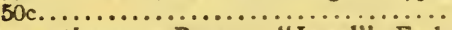

Leucanthemum Praecos "Jewel". Early flowering form with smaller tlowers. oz. $60 \mathrm{c} \ldots \ldots \ldots \ldots \ldots \ldots \ldots \ldots \ldots \ldots \ldots . . .15 .35$

The Shasta Daisies will not prove $100 \%$ true from seeds, but the best selectiong will show a fine proportion of worts rhile plante

CHRYSANTHEMUM - Indicum. Hardy Chinese varieties in mixture.......................

Japonicum. Hardy Japanese varieties,

Japonicum, Praecox. Early flowering form of Japanese sorts, blooms first eearon from

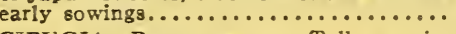

CIMICIFUGIA-Racemosa. Tall growing native. Graceful spikes of white flowers. native. Graceful spikes of white flowers.

GRSIUM-Velenowsk 1. (Velenowski's Orna. mental Thistle) White, changing to violet.

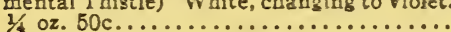

COREOPSIS - Lanceolata. (Tick Seed) Clear yellow. Oz. $45 \mathrm{c} \ldots \ldots \ldots \ldots \ldots \ldots \ldots$ Callfornia Sunbeams. Form of above with

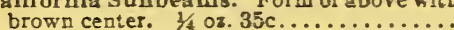
Verticillata. A fine hardy yellow border plant, persistent bloomer, with Nigella like foliage.

DELPHINIUM-(Hardy Larkspup)

Belladonna. Pale, sky blue, everblooming. Oz. $\$ 3.00$. 1/4 Ib. $\$ 8.00 \ldots \ldots \ldots \ldots \ldots$.

Bellamosum. Dark b!ue form of ebove.

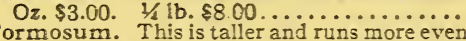

Formosum. This is taller and runs more even tions not subject to mildew it is far superior.

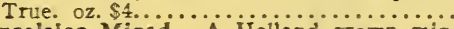

Excelsior Mixed. A Holland grown mix. ture containing a good selection of both ture containing a good selection of both

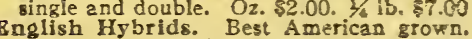
Bnglish Hybrids. Best American grown. second reproduction from Kelway's best hybrids. Single and double in ail color: $1 / 4$ oz. $75 \mathrm{c} .1 / 2$ oz. $\$ 1.25,1$ oz. $\$ 2.25 \ldots . .$.

Gold Medal Hybrids. A good straia of strong growers, suitable for outside sowing in quantity plantings. $1 / 2$ oz. $75 c_{.}, 1 \mathrm{os}$.
$\$ 1.50,1 / 4 \mathrm{lb}, \$ 5.00,1 \mathrm{lb} . \$ 18.00 \ldots \ldots \ldots \ldots$
10.25

\section{.85}

70

.35

$.15 \quad .35$

10.25

10.25

$.10 \quad .28$

$10 \quad .25$

10.25

$.13 \quad .85$

$10 \quad .25$

15.85

.15 .25

.10
DELPHINIUM-Continued

The very highest grafe deiphiniums, largest singles and best doubles, give a very light seed, of weak germination and compar. atively short keeping quality. Flowers from the strains offered below will be wonderful in quality, and plants will be large and strong. I do not recommend planting the seeds out side except in a most sheltered situation. Also do not attempt them after Sept. first. After that time we will hold orders for fresh stock, which should be barveated soon. The natied sorts will not come true, but colors and types will predominaie.

I have tried, and seen on other places. about every strain of delphinium offered on earth. I have seen none better than these offered below, but I have seen many not nearly as good, though held at bigher prices.

Admiral Jellicoe. Pale blue, inner petais rose. Large eye striped black and rose.

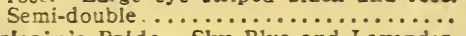

Brltain's Pride. Sky Blue and Lavender. with white center. Semi-double........

Glory. Lavender pink. The nearest laven-

His Excellency. Briliant blue, red inner petals. Semi-double. $1 / 6 \mathrm{cz}$. \$1.25.... Jessie Harrison. Light blue, Light rose inner perals. Small white eye. Double. 1/ oz. $\$ 1.25 \ldots \ldots \ldots \ldots \ldots \ldots \ldots \ldots \ldots \ldots$

Lovely. Milky lavenderand sky blue. Large white eye. Double. 1/ oz. \$1.50 ....... sacaulay. Sky blue, touched with pink.

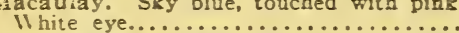
Amos Perry. Rosy mauve, iouched blue, outer petals touched sky blue. Sem double. $1 / 4$ oz. $\$ 2.00,1 / 20 z$. $\$ 3.75 \ldots . . .$.

Queen Mary. Lavender and blue. Whit eye. Semi double. $1 / 8$ oz. \$1.25, 1/4 oz.

KIns of Delphiniums. Gentian blue and

pium. Large white eye. Semi double. A giant. $1 / 4$ oz. $\$ 2.00,1 / 2$ oz. $\$ 3.75 \ldots .$.

Finest English doubles in light blue shades. $1 / 1$ oz $\$ 2.00,1 / 2$ oz. $\$ 3.75$. Worth the price Einest Enflish doubles in dark blue shadea, 1/4 oz. \$2.00, 1/2 0z. \$3.75. Same strain as

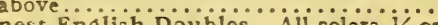
inest English Doubles. All colors $3 / 4$ or Wresham Hybrids. Immense flowers, singles and doubles in fine colors. A grand mixture. $1 / 4$ oz. $\$ 2.50$.

Hollyhock Strain. A new English production. Immense termiral heads of single and double flowers with no branches prevail in this mixture. 1,4 oz, $\$ 2 . . . .$.

Nudicaule. Dwarf scarlet, very slow to germinate. Scarlet. 1/4 oz. $75 \mathrm{c}$................ Zslil. (Sulphureum) A weas growitg yellow

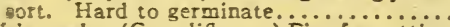
Chinersts. (Grandiflorum) Fine fö cuting. Stuft tittle plants. about 18". Blooms first zeason from sceds. Separate, white, iight bitue dark blue $1 / 402.35$................. DODECATHEON-Media. American Cowalip (Shooting Star). Lilac to Purple........ DORONICUM - Caucasicum. Sunflower like yellow flowers on terminal stems in early Epring. Very hard to handle. 25 seed ICTAMNUS-(Gas Plant) Red, white of mired. $\mathrm{Oz} . \$ 400 \ldots \ldots \ldots \ldots \ldots \ldots \ldots \ldots$.

.351 .00

\section{Dianthus}

Note, Dianthus Scotch type, Dbl. Dxf. Erfurt, Single Rock Superbus, Caesius, and Cyclope, all come under the bead of what is known as "hardy" or "grass" pinks. Deniosus and Deltoides are distinct, xith finer cut foliage of dark green, and smaller flowers. All flower the second season, a few the first.

Single Scotch. Shades of light and dark

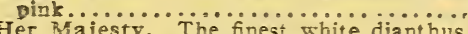
Will come slithly various .

Early Blush. Scotch type, L.ght pibk......15.60

- Lentosus Hybridus. (Amoor Pink) Lilac .15 10

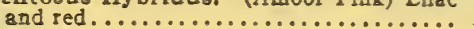

Footings -

Eootinge -

NOTICE-Instead of writing out longlists, Items may be checked and footed and the catalog returned to us. A new one will be sent with the seeds. See outside back cover. 
Pkt. Pr.

Pkt. Prt.

\section{DIANTHUS-Continued}

Double Dwarf Erfurt Finest doubles mired. The best commercial strain. 1/6 cs. $76 c_{1}, 0 x . \$ 1.50 \ldots \ldots \ldots \ldots \ldots \ldots \ldots \ldots \ldots \ldots .10 . \ldots$

Semperfiorens. Singles. Oz. 60c........

Single Rock (Alpine) Small fowered, eingle, elented.......... . . . . . . . . . . . . . . . . . ered with brilliant rose colored fowers in June. A grand and easy border plant. $1 / 6$

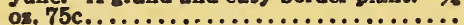

Doltoldee Alba. Indentical with above except color............................

Deltoldes Major Stearns Variety. Brown foliage, brilliant crimson flowers. Fine, New balls of spiky glaucous foliage. Pink flower. 100 seeds $25 \mathrm{c}$.

Cruentus. Deep blood red, mall, $1 / 4$ os.

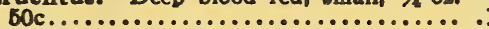

Superbue. Lilac, tall, $1 / 4$ os. 40 c.......... 10

Cyclope Hybrids. Rose and red vare in aingle and double...................

DIANTHUS BARBATUS-(Sweet William)

Johnson's Giant (true). The finest of the Sweet William mixtures. Giant flowers in marvelous colorings. Brilliant crimsons, white margined reds, pinks, etc. 1/4 oz.

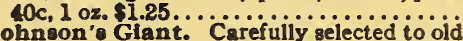

Johneon'e Glant. "Carefully selected to old For the old fashioned garden this is ideal The best light colored mixture. 1/20s. $\$ 1.00$

Johneon's Giant (Stock Seeds) Saved for our own owing. Taken from best indi. viduals only. The best mixture of Sweet viduals only, The best mixture of Sweet

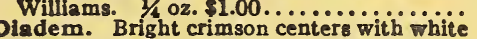
margin. A fine border, 10\%. $1 / 40 z .50 \mathrm{c}$...

Pink Beauty. Rosy salmon pink. $1 / 603.40 \dot{\mathrm{c}}$

Scarlet Beauty. Bright scarlet. Not as well eatablished as the other named sorts. $1 / 6$ oz. $50 \mathrm{c} \ldots \ldots \ldots \ldots \ldots \ldots \ldots \ldots \ldots \ldots \ldots . . . \ldots \ldots$

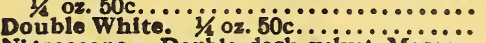

Nigrescens. Double dark velvet Maroon.

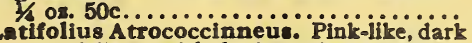
green foliage, with double velvety crimson fowers. In bloom from June till snow fall. The everblooming Sweet William. Fine

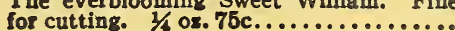

DIGITALIS-(Forglove) Glozinaeflora. Fine spotted. White, rose, purple or

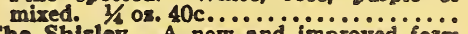

The Shirley, A new and improved form

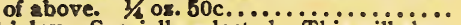

Shirley. Specially selected. This will show many more of the giant flowers than above. Impossible to furnish in quantity.

Busbaumil. Buxbaum's Golden Yello:

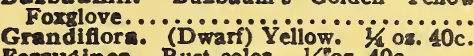

Perruginea. Rust color. 1/40z. 40c.....

Hybrida Lutz. New hybrids in salmon

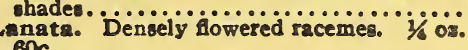

raculata.. "Finèy spotted dwar, mired.

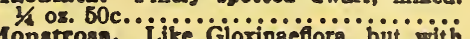

Monstrosa. Lijke Gioxinaeflora, but with the addition of one very large hower, well GNTRA-Eximen, Dwarf everblooming Bleeding Heart. $1 / 60 z . \$ 1.00 \ldots . . . \ldots .$.

DIPSACUS-Lacinatus. (Lacinated Teazel) Tall rose colored flowers, ornamental, $1 / 4$

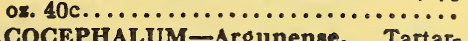

DRACOCEPHALUM-Argunense. Tartarian Dragon's Head, Light blue......... 10

ECHINOPS-(Flowering Thistle)

Sphereocaphalus. Light blue, small .......
Ritro (Blue Globe Thistle) Ball Shaped

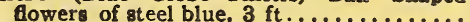
Humilis Cyanae. (Dwarf Giobe Thistle)...

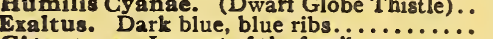
Giganteus. Largest of the family........... I

EPILOBIUM-Adenocaulon. Tall, large

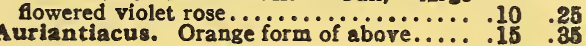

BREMURUS BUNGEII-Perfecta. One of the largest perennials. Spikes reaching 8 With yellowish white flower... . 35 Wallace's Hybrids. Wonderful range of new colors.................................. Bane early white, fine for cutting............. peciosus Hybridus. Lilac and blue shade Multiradius Roseus. Lilac rose, fine..... Quakeress. Tall, long stemmed, Rosy

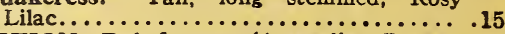

ERPETION-Reinforme. (Australian Pansy)

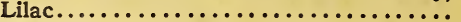

RRYSIMIUM-Pulchellum. Free flowering yellow.............................

ERINUS-(Alpine Liver Balsam) Alpinus.

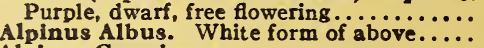

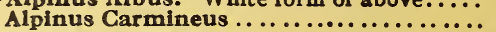

ERYNGIUM-(See Holly). All items in this are fine for winter bouquets.

Alpinum. True Alpine thistle, turns all blue after flowering. $1 / 2$ oz. $75 \mathrm{c} . \ldots \ldots \ldots$ Bourgati. Blue bracts and divided glaucous leaves. Heads small and very numerous.

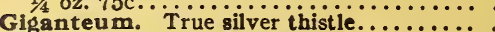

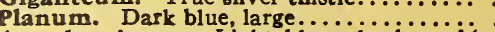
Amethystinum. Light blue, slender. i/

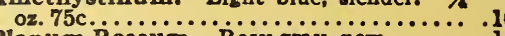

Planum Roseum. Rosy gray, new............

ESCHSCHOLTZIA-Caespitosa. A dwarf with ${ }^{a s}$ small yellow flowers. Very early bloomer.

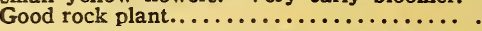

EUPATORIUM-(Thoroughwort) Fraseril.

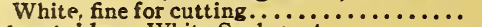

Ageratoldes. White Snakeroot . . . . . . . . Coelestinum. Fluffy heads of blue flowers in late fall, fine for cutting .............10

Purpureum. Tall, French $\mathrm{P}$ urpie, fine.....

SERLA-Gigantea. (Giant Fennell). Fine for tall groups, or for lawn specimens. 10

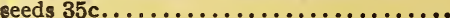

-gRANCOA-Ramosa. (Bridal Wreath) White .15

Ramosa Hybrida Rosea.................

PRAGARIA-Indica. (Indian Strawberry) Yellow flower, small scarlet fruits. Very ornamental creeping border. Easy........10

PUNKIA - Undulata Variegata. Dwarf, green and white, purple lavender flowers.........15

- GAILLARDIA - (Blanket Flower) Grandiflore Hybrids of Lady Rolleston. The best pogsible mixture. $1 / 40 z .25 \mathrm{c}, 0 z .60 \mathrm{c} . \ldots . . .10$

Bosselaeril. Brownish crimson and yellow . I5

Compacta. Compact grower, free, $1 / 40 z$.

Compacta. Compact grower, 1 . 14 oz. 10

Maxima Këmesina. M... Mostly crimson zones on yellow. $1 / 40 z .40 \mathrm{c}, 10 z$. $\$ 1.25 \ldots$ Le Mastodonte. Yellow, with red center, no colored zone. $1 / 4$ oz. $50 \mathrm{c}, 1$ oz. $\$ 1.25 \ldots$ Selected. Straw yellow, with deep rose zone. Some almost white, getting away from the objectionable red 'n yellow, which so often clashes in the border. Many of these give all the effect of the annual chrysanthemum "Burridgeianum." Our own selection not obtainable elsewhere.

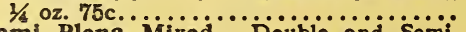

Semi Plena double forms. Unusual and very pretty. $1 / 40 z .75 \mathrm{c} . \ldots \ldots \ldots \ldots \ldots \ldots \ldots \ldots \ldots \ldots$ GALEGA-(Goat's Rue) Officinalis. Light lilac blue, Locust-like foliage, $18^{\prime \prime} \ldots \ldots \ldots$....

Ofi. Nana Rosea. Dwarf, double, rosy lilac. Fine for cutting. $1 / 40 z .75 \mathrm{c} . . . . .$.

-GENTIANA-Acaulis. Intense blue, with yellow markings. . . . . . . . . . . . . .

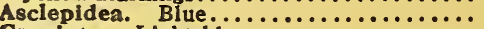
Cruciata $_{\text {Light blue. } \ldots \ldots \ldots \ldots \ldots \ldots \ldots \ldots}$

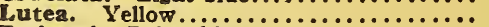

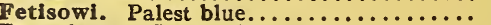

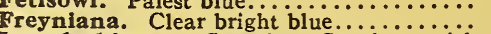
Lagodechiana. Creeping Gentian, with large flowers of bright blue. A fine rock plant. A. M. R. H. S. '21............... 501.25 Purpurea. Purple above, tube yellowish.. .15 1.35 -OEUM-Coccinneum. Mrs. Bradshaw, Double

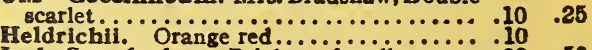
Lady Stratheden. Bright, soft yellow, new .20 .50

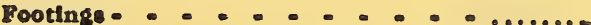

Pootings - - - . - - . -,$\ldots \ldots \ldots$

NOTICE-Instead of writing out long lists, items may be checked and footed and the catalog returned to us. A new one will be sent with the seeds. See outside back cover. 
Pkt. Pr.

Pkt. Prt.

GLAUCIUM-Burbank's Hybrids. Poppylike perennial with various colored cup

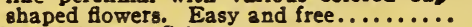

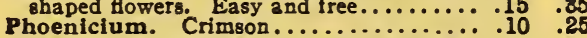

GLOBULA RIA-(Hairy Flowered Globe

Flower) Trycosantha . Dark blue........ .10 .25

Cordifolia. Fine and easy dwarf border. Neat rosettes of dark green (evergreen) leaves, round flowers of dark blue on clean $8^{\circ}$ stems. Easy and free...................

* GNAPHALIUM-Decurrens. White ever-

GUNNERA-Scabra. (Giant Rhubarb). $25{ }^{.15} .35$ seeds, 25c............................ ulata. The common single white, fine for cutting. $1 / 4$ oz. $25 \mathrm{c}, 1$ oz. $50 \mathrm{c} \ldots \ldots \ldots \ldots$ G. F1. P1. Double form of above, 100 seeds

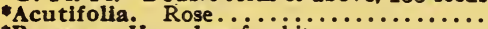

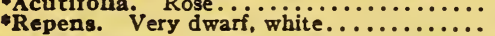
HEDYSARIUM - Coronarium. (French

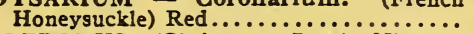

HELLEBORUS-(Christmas Rose) Niger. white.............................

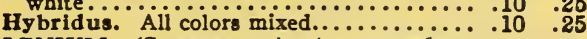

HELENIUM - (Sneezewort) Autumnale,

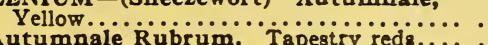
Autumnale Rubrum. Tapestry red $\mathbf{k}$.... Riverton Beauty. Yellow with black eye. Riverton Gem. Old gold and wallelower red ............. (Sü abLIANTHEMUM - (Sun Rose) Mut-
abilo Mired. All colors from yellow to deep rose. Fine border. $1 / 4$ oz. $40 \mathrm{c} \ldots \ldots \ldots \ldots$

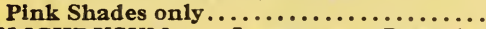

-HELICHRYSUM - Lanatum. Perennial

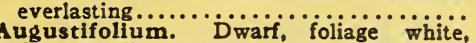
flowers yellow....................

HELIANTHUS - (Hardy Sunflower.) Mixed

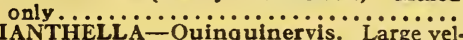
low flowers on $31 / 2 \mathrm{ft}$. stems. Fine and

HELIOPSIS - (Orange Sunflower) Pit-

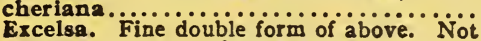
100 per cent true from seeds.............

HEMEROCALLIS - (Yellowi Day Lily) Dr. Regel, Deepest orange, early........

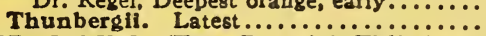

HERACLEUM - (Tree Parsnip) Wilhelmsii Mantegazzanum. Largest of the tree par-

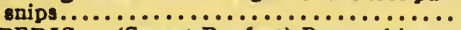

HESPERIS - (Sweet Rocket) Rose, white or mixed. 1/6 oz. 30c............................

HEUCHERA - (Alum Root) Sanguinè.

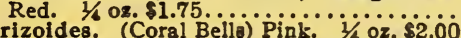
Brizoides. (White Coral Bells). White. $\$ 2.00$ Alba. (White Coral Bells). White. $1 / 60$. Convallaria Carnea... (Pink Lily of $^{\$ 1.00}$ the

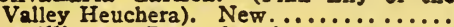

- Gracillima. Rose, heavier grower thà

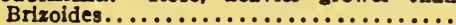

HIBISCUS - Giant Meehan's Mallow. Mixed. Oz. 60c....................... Meehan's Mallow. From selected reds.
Oz. $\$ 2.50 \ldots \ldots \ldots \ldots \ldots \ldots \ldots \ldots \ldots$ Oz. $\$ 2.50 \ldots . . \cdots$ White. with red eye.

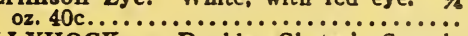

HOLLYHOCK - Double, Chater's Superb, in the following separate colors, white, rose, crimson, maroon, salmon. Newport pink, yellow or mixed. 1/6,0z. 30c, 0z. $\$ 1.00$ Chater's Double. In the following novelty shades: Carmine, purple, cream, salmon red, rose overlaid yellow, lilac, apricot, light red, yellow on dark ground, wallflower shades, chamois, white with purple, or

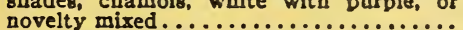

Double Exquisite. ' Large flower... closely set on long spikes. Every petal, both edge and center, is curled and fringed. Flower extremely double, and as high built as a double petunia. Each white margined petal is spotted with a large pelargonium blotch, giving this new item a very distinct and attractive appearance. There are no strong reds, making the mix. There are no strong reds, making the mix.
ture rather light colored................
HIERACIUM - Auriantlcaum. Dwarf

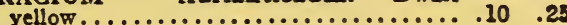

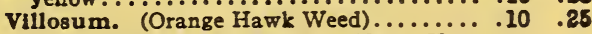

HYACINTHUS - Candicans. (Cape Hyacinth), Easily grown bulbous plant, with

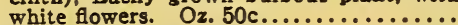

HYPERICUM - Elegans. Bushy perennial, with single yellow flowers, good.........

-IBERIS - (Candy Tuft) Sempervirens.

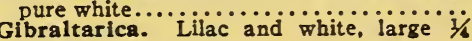
Gibraltarica. Lllac and white, large $1 / 6$

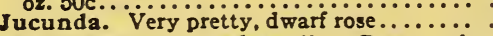
INCARVILLEA - Delavayii. Rose red,

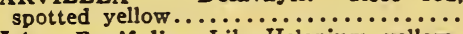

*INULA - Ensifolla. Like Helenium. yellow. Grandiflora. (Gold Marguerite)......... Roleyana. Deep orange, fine............ 20

IRIS - Kaempferil. Japan Iris. $1 / 4$ oz. $25 \mathrm{c}$. Uncertainty of crop prevents listing of and will gladiy send it when on hand at..

ISATIS - Glauca. Silver white foliage, yellow flowers................................. plant from western Asia. Dark blue......

CATHYRUS - Latifolius. (Hardy Sweet Pea). In the following separate colors: White, rose, pink beauty, violet rose, or

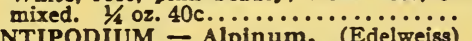

Sibericum. Resembles above, larger..... $.25 \quad .50$

LAVENDULA - Veris. True Lavender, $1 / 6$

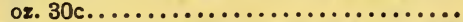

LIATRIS - (Blazing Star) Spicata. Purple rose................................

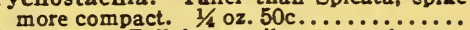
Scarriosa. Tall, loose spike, same color.....

LILIUM REGAL-Our stock of this is taken from bulbs that are held expressly for seed production, and will give the very best results, both in germinatio: and vitality. We plant in frames in early May. Seed germinates in about two weeks. Let the little plants stand 'as is' till fall, when the buibs should be lifted and stored in dry sand in a cool place, free from frost, and then planted out again in May. The $3^{*}$ deep in a permanent situation. Per pkt. 50 seeds, $15 \mathrm{c}, 250$ seeds, $50 \mathrm{c}$, per M $\$ 1.50$. Write for prices on larger auantities.

Lillum Martagon. (Turk's Cap Lily) Very well and favorably known abroad, where it is much used. Sow in fall for spring germination.

Martagon Backhouse Hybrids. ' M. Marta. oon X. L. Hansonil. Various colors in light pink and yellow shades, with dark spots.

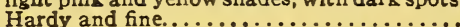

Sulphur Gale Hybrids. Regale $\ddot{X}$ Sulphur. eum. Deeper yellow than Regale, later, and stronger grower.............................

LIGULARIA - Macrophylla. Flowers yellow on long terminal racemes. Fine..........

- LINUM - Perennae, (Hardy Flax). Blue, white or mixed. $1 / 1$ oz. 25c, $1 \mathrm{oz} .50 \mathrm{c} \ldots \ldots$.

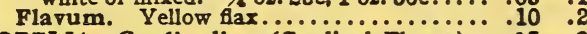
COBELIA-Cardinalis. (Cardinal Flower) . $15 \quad .25$ Syphilitica. Fine blue native 1.16 oz. 50c. $.20 \quad .50$

LUPINUS-Polyphyllus. Hardy Lupin. Blue

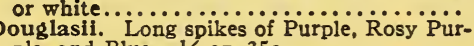
ple, and Blue. $1 / 4$ oz. $35 \mathrm{c} . . . \ldots \ldots \ldots$............ Downer's Hybrids. Fine range of colors. Elliott's Sweet Scented. Handsome spikes of sweet scented selfs and bicolors...........

Lavender Queen. New shade in Lupins. Queen. New shade in Lupin.

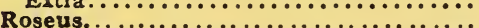

Golden Spire. Purple with Gold, $\ddot{1 / 4}$ os. $7 \dot{7} \dot{c}$

Evening Glow. Rosy Fawn with deep golden

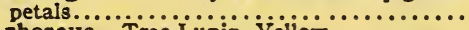

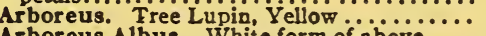

Arboreus Albus. White form of above.... White or mired. Bis. (Honesty) Violet,

- LYCHNIS - Flos Cuculi. Single Magenta

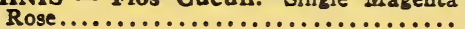

NOTICE-Instead of writing out long lists, items may be checked and footed and the catalog returned to us. $A$ new one will be sent with the seeds. See outside back cover. 
Plt. Pr.

Tr.
Pkt. Pkt.

\section{LYCHNIS-Continued}

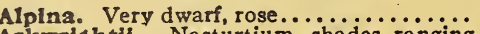
Arkwrightil. Nasturtium shades ranging from white through yellow, pink, to salmon

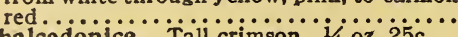

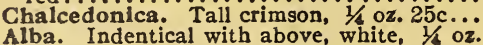
Alba. Indentical with above, white, $1 / 20 z$. Salmon Queen. (New) Same form as above, but a soft salmon pink................... Haageana Hybrids. Bright nasturtium shades, on 10 " stems, free. $1 / 1 / \mathrm{oz} .75 \mathrm{c} . .$. Sieboldil. Large flowered white............ Fulgens. Terminal clusters, bright scarlet
Viscaria Splendens. (Coccinnea) Single,

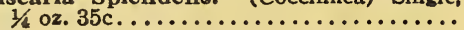

*MALVA-Moschata. (Musk Mallow). White, rose or mixed ...................

* MALOPE-Dwarf border plant, not reliably hardy. Crimson, white or mixed..................

-MATRICARIA-Capensis. (Mother Wort) Small button-like flowers with pretty finely cut foliage. Double white, double yellow, or mixed, easy................. (Night Scented Stock). Biennial. Reddish lilac only. $1 / 4$

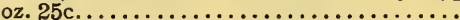

-MECONOPSIS-Cambrica (The true Welsh

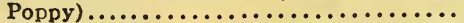

Wallachi. Blue Himalayan poppy. Biennial.

MONARDA-(Bergamot). Cambridge scar-

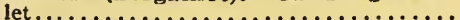
MONTBRETIA-Crocosmin̈ora. Mixed... *AYOSOTIS - (Forget-Me-Not) Alpestris Distinction. Early and everblooming. Alpestris. The deep blue of the type. $1 / 4$

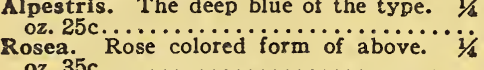
Alba. 35 c. White form of above $1 / 4$ oz. $35 \ldots \ldots$ Indigo. Dark blue form of above. $1 / 4$ oz. 35c........ Gitio.................... Perfection large flowered blue. E. Fonrobert. $1 / 4 \mathrm{oz} .60 \mathrm{c}$.
Palustris Semperflorens. Dwarf everPalustris Semperflorens. Dwarf ever-
blooming, blue. The best border myosotis.

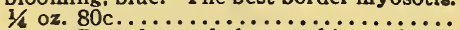

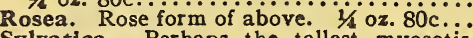

Sylvatica. Perhaps the tallest myosotis, blue..........................

- MIMULUS-Cardinalis. Scarlet.......... flowered Mimulus, in a new shade........

NEPRTA-Mussini. Small leaved catmint. A valuable everblooming dwarf border

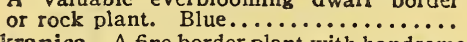

Ukranica. A fine border plant with handsome sprays of DARK BLUE flowers. Blooms all summer. Good rock plant............... O'THERA-(Evening Primrose) Youngil

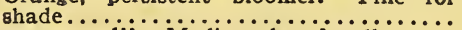

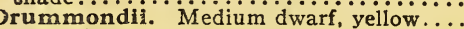
Lamarckiana. Large flowered, tall yellow. Missouriensis. Largest flowered, pale

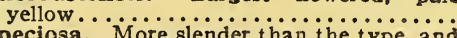
Speciosa. More slender than the type, and

PORDON-(Cotton Thistle) Bracteatum Large silver leaved spiky foliage, purple red flowers. Scotch Thistle, 5-7 ft. 1 oz

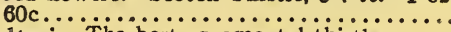

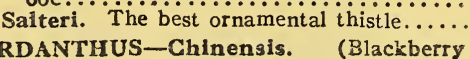

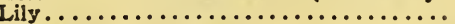

YTEUMA-Scheuchzeri. Dark blue, fine Alpine............................

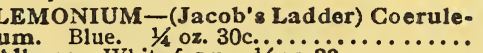
um. Blue $1 / 4$ oz. $30 c_{1} \ldots \ldots \ldots \ldots \ldots \ldots$ Richardsonil. $1 / 4,0 z .50 \mathrm{c} \ldots \ldots \ldots \ldots \ldots \ldots$ Repens. Dwarf blue, $1 / 4$ oz. $60 \mathrm{c} \ldots \ldots \ldots \ldots$ Himalayicum. Laiger flower than Coeruleum. $1 / 1$ oz. $50 c$ iibum..... White form of above. $1 / 20 z .50 c \ldots . . \ldots \ldots \ldots \ldots \ldots \ldots . . . \ldots$

15.35

$20 \quad .50$

10.25

.70

.35

.35

$25 \quad .70$

15.35 $.15 \quad .85$
PENTSTEMON-Digltalls. White purple

throat, hardy ...... isheli Pink. This

should give some good hardy hybrids.....

Torreyil. Taken from the old tall red.......
Gentianoides. Much used in England.

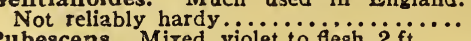

Pubescens. Mired, violet to flesh, $2 \mathrm{ft} . .$.

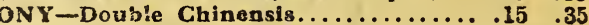

PHYSALIS-Franchetti. Chinese lantern

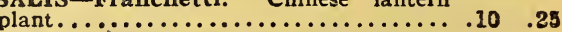

PHYSOSTEGIA-(False Dragon Head) Virginica. Spikes of pink flowers. Easy. Good

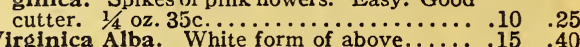

PHLOX-Decussata. Hardy phloxes taken

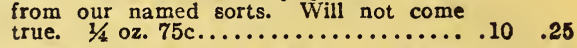

pOPPY-Orientale. Orange scarlet. $1 / 4 \mathrm{oz} .25 \mathrm{c} .10 \quad .25$

Mrs. Perry. Giant salmon pink. $1 / 4 \mathrm{oz} .85 \mathrm{c} .20 \quad .50$

Beauty of Livermore. Darkest scarlet. We have dropped Mahoney for this variety. $1 / 4 \mathrm{oz} .75 \mathrm{c} \ldots \ldots \ldots \ldots \ldots \ldots \ldots \ldots .15 \quad .35$

Giantea. Immense orange scarlet........25 .70

Perry's White. The best white...........25 $\quad .70$

Rembrandt. Orange scarlet, deeply

fringed. $1 / 4$ oz. $60 \mathrm{c} \ldots \ldots \ldots \ldots \ldots \ldots \ldots \ldots .15 \quad .35$

victoria Louise. Shell pink. $1 / 4$ oz. 75 c... .15 .35

Mauve. Not as large as other shades. Dull

Hybrid poppies will not come true from seeds, though most carefully segregated. They will, however, show upward of 50 per cent of the parent shades. Our plants as offered are grown from root cuttings and are 100 per cent true.

*POPPY-Nudicaule. Iceland Poppy, White, orange or mixed. $1 / 40 z .50 \mathrm{c} \ldots \ldots \ldots \ldots \ldots$

Scarlet. New ..................................

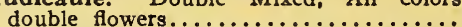

Sunbeams. Large flowered form of above. brighter and better color assortment.

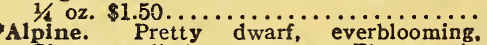
Glaucous little rosettes. Flowers in wonderful color assortment. Must be kept cool........................25 .70

PLATYCODON-(Balloon Flower)

Grandiflorum. Tall form, blue, white or mixed. $1 / 4$ oz. $50 \mathrm{c} \ldots \ldots \ldots \ldots \ldots \ldots \ldots$.

Grandifiorum. Double mixed.................... .50

-Maresil. Dwarf form, blue, white or

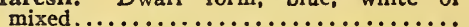

POLYGONUM-Sieboldil. White flowers, with ornamental foliage............... . . 35

FPTENTILLA-(Cinquefoil) Atrosan-

guinea. Crimson...................10.25

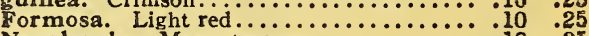

Nepalensis. Magenta rose....................

ERIMULA-(Primrose) Auricula. Large

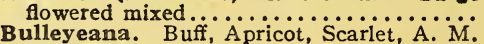
Rarr's Exhibition Reds. The finest strain

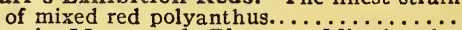
Barr's Munstead Giants. Mixed polyanthus in white, primrose and yellows. Extra in white, primrose and yellows.

Cortusoides. Slender stem, purplish rose.

Alleen Aroon. A long stemmed cross, containing many new shades. Must be kept cool...................................

Narrow leaves and violet purple flowers.

Moerhei mi Hybrlds. Heavy grower, large flowers on stiff stems. Stem and caylces covered with fine frost-like dust. Shade of orange, yellow, pink and red. Very distinct............................ ica in plant and form. Flower larger. Stem shows same characteristic as Moerheimi. Fine color range.............

Rosea Grandiflora. Very early, one of the finest. Rosy Crimson flowers........... Red Hugh. A pulverulenta type. Brilliant
crimson. Blooms in umbels, sometimes showing three in succession. Dies to the ground in summer. A fine primula....... .2
$25 \quad .65$

351.00

Bootinge - - - - - - - . .......

Footinge - - - - -

NOTICE-Instead of writing out long lists, items may be checked and footed and the catalog returned to us. A new one will be sent with the seeds. See outside back cover. 
Pkt. Pr. PRIMULA-Continued

Veitchit. Mostly purple. A fine primula. $.25 \quad .60$ Veris Gigantea. A fine strain of the best known primrose, easiest grower. Mixed

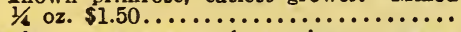
Veris. n separate colors, crimson, orange

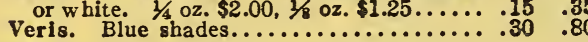
PYRETHRUM-(Feverfew) Roseum Hybridum. Good color range, carefully $8 e-$ lected on our own grounds. Not 80 per cent whites as usually offered. $1 / 4$ oz. $35 \mathrm{c}$

Atrosanguineum. Red shades in mixture. $1 / 1$ oz. 75 c ................................... Carneum. Pink shades in mixture. $1 / 40 z$ oz.

James Kelway. Giant fiowered bright vermilion. Larger plant, larger seed. $1 / 8$ o2. 90c............................ Taken

Best Doubles in Mixture. Taken from flowers unequaled. Round as a ball, fine
color range. Should show 80 per cent

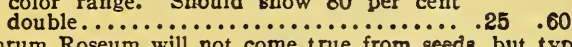
Eyrethrum Roseum will not come true from seeds, but type and color will greatly predominate.

single mixtures as we have had them from the best sources have shown largely of whites. The seed offered above is from our own plants, from which most of the whites were removed.

Note, the doubles will not show over $60 \%$ double. Do not make selection until the second season of bloom. First bloom is not typical, and will show upward of $95 \%$ single.

RANUNCULUS-Asiaticus. The best of the Asiatic or bulbous Ranunculus............. $.15 \quad .35$

"RAMONDIA-Pyrenaica. Often called Alpine Violet. (Rosette Mullein) requires protection. Fine pot plant for the house

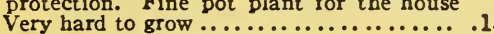

ROMNEYEA-Coulteri. (Poppy Mallow) Large white poppy-like flowers........... . 10

RUDBEGKIA - (Cone Flower) Fulgida. Brilliant Rudbeckia, orange yellow. $1 / 6$

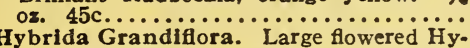
brid Rudbeckia, golden orange. $1 / 40 z .45 \mathrm{c}$

Newmanii. Orange yellow, black center.

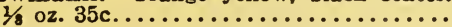
Purpurea. (Giant Purple Cone Flower). 1, oz. 40c.........................

-SAPONARIA-Ocymoides Splendens. Fine pink creeper.......................10

Ocy moldes Alba. White form of above... 10

Officinalis. (The Bouncing Bet. of our roadsides) ........................

-SCABIOSA-Caucasica. Pale blue, perennial. $1 / 4 \mathrm{oz} . \$ 1.00,1 \mathrm{oz} \$ 3.00 \ldots \ldots \ldots \ldots$

Alba. $1 / 4$ oz. $\$ 1.00 \ldots \ldots \ldots \ldots \ldots \ldots \ldots .20$

Japonica. Pale blue, biennial. $1 / 2$ oz. 75c. .10

*SALVIA-Argentea. White flowers, silvery, woolly foliage. $1 / 4 \mathrm{oz} .35 \mathrm{c} .2 \mathrm{ft} . \ldots \ldots \ldots$.

Farinacea. Pale blue. Blooms first season if sown early. Not reliably hardy. Pro-

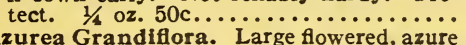
$5 \mathrm{ft}$. Fine for backgrounds. $1 / 4 \mathrm{oz} .60 \mathrm{c} . .$.

Globosa. Very free and easy white flowered form. Silver white foliage. $3 \mathrm{ft}$. $1 / 6$ oz. 30c................................. Blue real blue in the floral kingdom." $1 / 8$ oz.

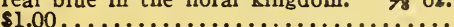

Pratensis. lue, often sold as Patens......

Ringens. Large reddish purple........... 15

Turkestanica. Alba, w vite flowers. $1 / 4 \mathrm{oz}$. $35 c \ldots \ldots \ldots \ldots \ldots \ldots \ldots \ldots \ldots \ldots \ldots \ldots \ldots \ldots \ldots . .25$

Rubra. Free, red flowering. $1 / 4$ oz. 35c. $.10 \quad .25$ Both this and above are very ornamental. Flower is not significant, but the leaf bracts at heads of the plant are very striking. Not used enough. Easy and free

Salvia. From the Vatican Gardens. A type of Turkestanica but much more showy. $3 \mathrm{ft}$. Branching heads of flowers in white and lavender. Easy...................

-SAXIFRAGA-Megasea Hybrids. Large flowered mixed..................... The

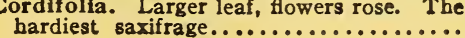

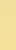

*SEMPERVIVUM-(House Leek). Dull greenish red rosettes................... . .35

SENICIO-Cliverun. Heavy growing perennial with heads of yellow flowers, late bloomer. Ornamental.................

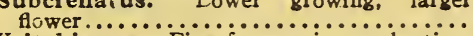

veitchianus. Fine for specimen planting. Wide spreading tuft of large cordate leaves. Heavy stems reach three ft. with yellow flowers along the upper two feet. Very

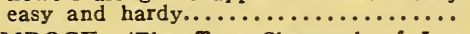

* SHAMROCK-(The True Shamrock of Ireland.) $1 / 4$ oz. $75 \mathrm{c} \ldots \ldots \ldots \ldots \ldots \ldots \ldots \ldots$

SIDALCEA-Candida. A tall white flowering plant. Fine for waterside. Sow in fall... Rose Queen. Pretty rose colored form of

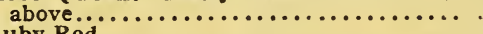

New Hybrids. Ranging from deep rose to white $\ldots$. ..................................... white heads on $2 \mathrm{ft}$. stems Very oini-

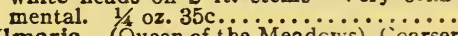
Ulmaria. (Queen of the Meadcws). Coarser leaf, white...................................
Astilbe. Mixed, taken from such items as Gladstone, Queen Aiexandra, etc., the forcing types ............................... Aruncus, A hybrid resembling Astilbe.
Hardier, heavier grower. $1 / 40$ oz. $\$ 1.00 . .$.

SILENE-(Catch Fly) Grandiflora. Crimson scarlet.......................... Alba. Same as above, white flowering. $1 / 4$ oz. 40 c......................................... Orientalis. Red......................

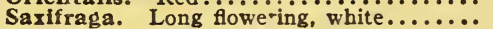
SOLIDAGO-Canadensis. (American Golden

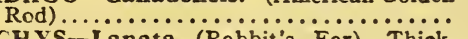

"STACHYS-Lanata (Rabbit's Ear). Thick, woolly leaves, pale blue flowers. Dwarf.

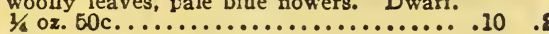

Alplna. Deep rose, dwarf .................. 15

STATICE-(Sea Lavender) Latifolia. Most used for winter flowers, or for summer cutting with other items. $1 / 6 \mathrm{oz}$. 50c. Clean seeds, $1 / 4$ oz. $\$ 1.25 \ldots \ldots \ldots \ldots \ldots \ldots .10$

Eximea. Lilac pink ..................

Tartarica. Larger than Latifolia, coarser.

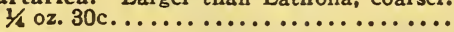

STOKESIA-(Stoke's Aster). White, blue,

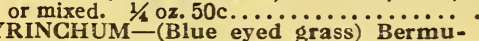
dianum. Grassy foliage, blue flowers in spring and fall ....................

THALICTRUM-Adiantifolium. Adiantumlike foliage, white flowers. $1 / 40 z$. $\$ 1.00 .$. Aquileglafolium. (Tufted or Feathered Columbine) Mixed. $1 / 4$ oz. $75 \mathrm{c}$........... Aquilegiafolium Purpureum. Dark rose ers in June and July. Good for wet places.

Glaucum. With yellow flowers wet places.

DIpterocarpum. This is one of the hand. somest perennials in this entire list. Given a good part shade and fairly heavy soil, it is perfectly hardy. Buds resemble pearls, opening to delicate lavender flowers, with yellow centers. $1 / 40 z$. $\$ 1.25 . \ldots \ldots \ldots \ldots$.

TRITOMA (Red Hot Poker) Express. A mixture of early sorts. $1 / 4 \mathrm{oz} .50 \mathrm{c} . \ldots \ldots$....

May Flowering Hybrids. $1 / 8$ oz. $50 \mathrm{c} . \ldots \ldots$....

Red Seedlings-Taken from all Reds ........20

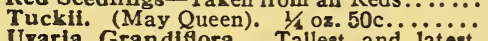

1/40z. 50c......................

Tritomas do not come true from seeds, but the variety named will predominate.

TROLLIUS-Caucasicus. (Orange Globe Flower) Orange globes. $1 / 4$ oz. $\$ 1.00 \ldots$.

Ledebouri. This is one of the best of Trollius. Tallest and largest flowering, latest to bloom ............................. (European

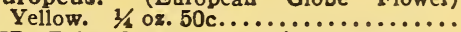

TIP. Taken from best Darwin types, mixed. TUNICA-Saxifraga. Finely cut leaved dwarf border. Small pink fowers, easy, free. $1 / 4$ oz. 25 c......................

$.10 \quad .25$

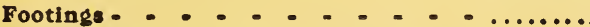

Footings -

NOTICE-Instead of writing out long lists, items may be checked and footed and the catalog returned to us. A new one will be sent with the seeds. See outside back cover. 
VALERIANA - (Vaierian). White, rose-red, or mixed. $1 / \%$ os. $40 \mathrm{c} \ldots \ldots \ldots \ldots \ldots \ldots \ldots$.

Officinslls, The best Valerian. Has never seeded with us. Imported seed. White. Yo oz. 60c........................18

VERBASCUM-(Moth Mullein) Giganteum Silver white foliage, yellow flowers, tall. $1 / 202.40 \mathrm{c} \ldots \ldots \ldots \ldots \ldots \ldots \ldots \ldots \ldots \ldots . . \ldots \ldots$

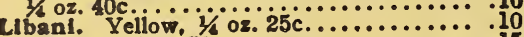
White. $1 / 3$ oz. $50 \mathrm{c}$.................. hades of yellow fine $1 / 108.25 \mathrm{c} . . . . .$. . ONICA - (Speedwell) IBackhofeni. Light

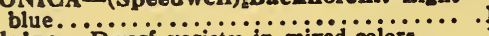
Alplne. 'Dwarf variety in mixed colors...... 16 CandIda. Silvery leaves. Light blue. i/

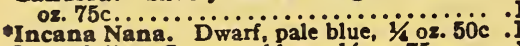

Longlfolla. Compact blue. $1 / 1$ os. $75 \mathrm{c} . . . .10$ Longlfolla. Compact blue. 1/ os. 75c.... 10

True Blue. Of Spicata type, everbloomlng, slender stems of royal blue, new........

spicata. Mixed Rose, White, Blue, $\ddot{y}$ os. 10c.....................................

Teucrium. Royal Blue. BENA-Aubletia Grandifora. (Large
flowered Rose Vervian). American native. Colorado, New Mexico, Texas, 12-18\%, rose purple, tender in the north, requires protection. "It is to be regretted that thlo charming species, so well thought of is Europe, should be neglected in its native America." (Mr. Cowen, in Bailey's En-

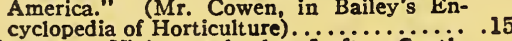

*Venose. Violet, velned. $i$ it. South American native. Like above, requlres protection in the north. Root is bulbous .15

-VIOLA -(Tufted Violet) Alba ............ 10

Admiration. Deep blue. $1 / 6$ oz. $60 \mathrm{c} . . . . .$. Just now in great demand................30

Perfecta Cream. $1 / 6$ oz. $60 \mathrm{c} \ldots \ldots \ldots \ldots \ldots$

Purple King. Scotch Border type, large. Finest large purple. $1 / 4$ oz. $75 c \ldots . \ldots \ldots$.

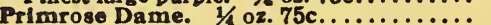

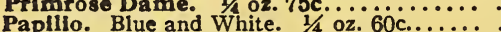

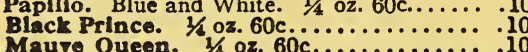

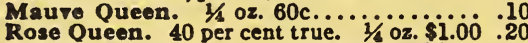

Thuringia. Blue with White Eye. $1 / 4$ oz.

60c. . . . . . . . . . . . . . . . . . .

Scotch Border. Like pansies and almost as large, good assortment of shades. In bloom the entire summer. $1 / 1 / \mathrm{oz} .75 \mathrm{c} . . . .10$

Scotch Border. Taken from our magnificent collection of named sorts....... .20

-VIOLET-Prince of Wales. Deep blue....... .15

WALLFLOWER-Single mixed. $1 / 6$ oz. 35c .10 Double Mixed. 1/20z. $\$ 1.00 \ldots \ldots \ldots \ldots \ldots . .20 .50$

\section{Ornamental Grasses}

ANDROPOGON-Argenteus. Silver white beard grass. Fine for drying.........................

ARUNDO-Donax. (Great Reed) The tallest RROMUS. Requires protectlon................... BROMUS-Uniololdes, Pendulous. Pretty .155 ELYMUS_Giganteus. (Giant Bunch Grass) .10 .25 ERIANTHUS-Ravennae. (Ravenna Sugar Grass) Very hardy, tall................

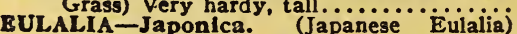
One of the most used grasses. Green, with

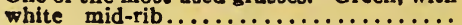

- EESTUCA-Glauca. (Äpine Bunch Grass) Neat little tufts of glaucous green.......

- Alpina. Like above but more on the bluish

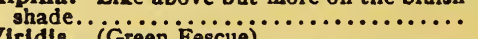

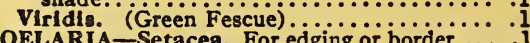
KOELARIA-Setacea. For edging or border ....
LISIAGROSTIS-Argenta. Fine for cutting, LISIA MELICA -Altissima. (Tâl Peari Grass) .......... PANICUM-VIrgatum. (Twiggy Panic Graes) Flne for winter bouquets.............. "drooping" border for tall beds or borders. Much used in parks and public grounds. Not hardy.....................

Macrourum. (Long Tailed Pennisetum)

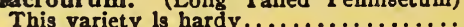

STRLLARIA-Graminea Aurea. Not strictly a grass, but with yellow, grass-like foliage. White flowers. Fine rock plant......... STIPA-Pennata. (Feather Grass) ........... $\quad .25$ UNIOLA - Latfolla. Large seed heads, pretty .10 . 10

\section{Vines}

ASPARAGUS - Acutifollus. Recommended for green for cutting. Requires protection.

ADLUMIA - Cirrhosa. (Allegheny vine) Useful climber, with finely cut leaves.

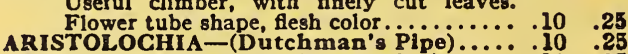
AMPELOPSIS-Veltchll (Boston IVy) ......... BIGNONIA-Radicans. (Trumpet Creeper) :10 .25 CLPMATIS-Much used hardy climbers, very ornamental.

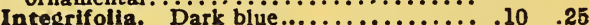

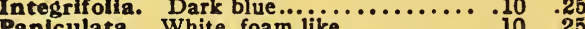

Grandiflora Mixed. A mixture of the large flowered named sorts...................... $\quad .50$

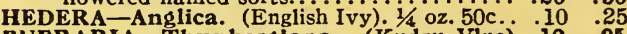
PUERARIA-Thunberglana. (Kudzu Vlne) .10 .25 WISTARIA - Magnifica. Pea shaped laven-

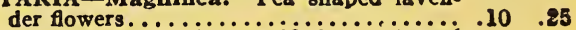

Vine seeds should be stratified, or planted

in August to come the next spring.

We do not carry seeds of Ornamentals, Trees or Evergreens in stock but will be glad to procure any varieties wanted on request.

Footings

Footings - - - - - - - - $\ldots \ldots \ldots$

\section{Annuals for Fall Sowing}

It is not generally known that many of our best and prettiest annuals may be sown in the fall, and that some of them sre even better if fall own. Among these are Alyssum, Antirrhinum, Calendula, Calliopsis, Candytuft, Centaureas, Cranealandi़l Imperialis, Clarkia, Cosmos, Dianthus, Escholtzia, Euphorbia, Godetia, Gypsophila, Hunnemania, Kochia Larkspur, Marvel of Peru, Didiscus, Linum, Lupinus, Nemophila, Nicotiana, Nigella, Petunia (bedding vara). Phlor Drummondil, Poppy, Schizanthus, Verbena. Sweet Peas asy also be sown in fall, but personal experience here has sown that our frigld Ohio springs are rather hard on the seedlings. All the above will be found in splendid variety in our list of annuals.

Plants from fall sown seeds are hardier, with better root system, and can be transplanted in the cool, wet weather much easier than those from the spring sowings. They will bloom earlier, and blooming season can be greatly lengthened if both fall and spring sowings are made.

Notice-Care should be taken not to sow to early, else the seeds will germinate and seedlings will winter kill. Early November is the best time in this section.

FOTICE-Instead of writing out long lists, items may be checked and footed and the catalog returned to us. A new one will be sent with seeds. 


\section{CONCERNING PERENNIAL SEEDS AND A FEW OTHERS}

Poor germination of seeds makes a fine chance to lay something up against the long suffering seedsman. I think, from years of experience with him, that the average seedsman is doing his level best to get you something that will produce results, and to give you a dollar for the dollar you spend with him. Barring a few scarce perennial seeds, I doubt if there are any seeds held over for one year. Failure may result from so many causes that even our expert growers are not likely to lay failure to old seeds on a first trial. Many items either must be fall planted, or are better planted at that time. These are, and have been for many years, a source of complaint, and of dark suspicion that the seedsman is sending out antiques. Among these are Adonis, Aetheoppapus, Anthericum, Apocynum, Asperula, Cassia, Colchicum, Convallaria, Cirsium, Dicentra, Dictamnus, Ferula, Echinops, Gunnera, Hedysarium, Helleborus, Heracleum, Hypericum, Liatris, Morina, Oenothera (Missouriensis), Pardanthus, Peony, Phlox, Sidalcea, Spirea, Trollius, about all vine and shrub seeds. Above items, if planted in frames in fall, or if planted outside, and given some light covering to prevent heaving, will at once remove all suspicion as to any advanced age.

Then there's the really fine seeds, many of which should not be covered at all. Heuchera, Lobelia, Leontipodium, Gnaphalium, Erinus, Androsace and Giant Petunia, and other fine annuals, either should be covered very lightly, or else not covered at all.

Each spring we plant about two acres of perennial seeds, as time and weather will allow, from about April first to May fifteenth. Such large items as Hollyhock, Mallow, Centaurea, Gaillardia, Coreopsis, and like, invariably, barring accidents, give us a good stand, but the finer and more uncertain Campanula, Digitalis, Aquilegia (note that I offer these in two sections), Agrostemma, Double and finer Hybrid Delphiniums (Belladonna and Bellamosa are sure fire outside) Lychnis, and other medium fine seeds often fail, or after germinating meet up with weather conditions that put them out of the running. We expect little from these, however, and make all preparations to handle them in frames. When we do get a stand of them outside it saves much labor and time, so we always try them outside first.

When the grower is not able to be constantly with the seedlings, the ideal summer cover for the frames is common cotton cloth, next best is lath frames, spacing lath about $1 / 2$ inch apart. We also use glass, covered well with a paint made from white lead thinned with gasoline. This shades during hot weather and is mostly washed off by fall.

Prepare all seed beds, either frames or outside, by thorough plowing or spading, and raking, then for fine seeds level the soil and firm it lightly, scatter the seeds thinly, first seeing that the planting space is level, so that the seeds will not wash to one corner of the little block when watering. Then screen soil over the seeds to the depth of the size of the seeds, or so that they are just covered from sight. Water lightly with a fine sprinkler and await results. Do not allow the soil to bake.

\section{DON'T-Plant seeds deeper than the size of the seeds,}

Plant fine seeds in full sun in hot weather (Coarse seeds will do for you about as would lettuce, carrot, beet, or like items).

Plant seedlings out in the fall. Let them stand in seed rows or frame till spring, with light mulch.

Water too much, or with too heavy force. This breaks the tender little plants, and causes damping.

Use too much fertilizer on the little seedlings. Let them get large enough to "eat."

You will never get germination from poor seeds, but you will often get poor germination from perfectly good seeds, at least we do. The trouble lies almost invariably with something done wrong, too heavy, too light, covering; too much, too little water; wrong soil; too much, too little air. Use your plant or seed sense, study your conditions and you will be richly rewarded for a little time and less money spent in the most fascinating branch of gardening.

I will gladly help solve your planting problems, but please remember that you are one of many, and that I'm busy. Don't write until you know you cannot get results yourself.

Respectfully,

R. E. Huntington. 


\section{PLEASE MAIL TO:}

Name

Address.

County and State.

R. F. D. No.

Instead of writing lists of seeds desired, check items and return this catalog. A new catalog will be sent with seeds. 